\title{
British Overseas Military Commitments 1945-47: Making Painful Choices
}

In February 1947 the British government made a number of policy decisions which led to withdrawal from India, Palestine and Greece. The paper seeks to demonstrate that while economic constraints highlighted the need to reduce overseas commitments, these pressures did not predetermine the choice or timing of the withdrawal decisions. The consequences of the retreats in terms of reduced military overstretch, balance of payments alleviation and the diminution in Britain's international status are also examined. It is concluded that the Attlee administration shed a range of military burdens as rapidly and in as orderly a fashion as political and strategic circumstances permitted.

Key Words: military commitments, balance of payments, UK, Greece, India, Palestine

\section{Introduction}

In the space of a week during February 1947, at a time of major economic difficulties, the British government made a series of decisions which heralded the end of the Indian Empire, the termination of major United Kingdom (UK) military and economic support to Greece and the eventual surrender of the Mandate for Palestine. Two-thirds of a century later, it is worthwhile reviewing and to a degree reassessing the circumstances which resulted in such a substantial shedding of overseas obligations. The prime purpose of this article is therefore to demonstrate that, while the economic situation pointed to the urgent need to prune commitments, it did not predetermine either the choice or the timing of specific withdrawal decisions.

More broadly, the paper demonstrates that with finite resources, governments must make complex and often painful choices between alternatives. The cost of any decision is thus the value of the next alternative forgone - its opportunity cost. Hence, policy decisions involve 'trade -offs' in terms of the sacrifices incurred in using scarce resources for one purpose rather than another. This paper seeks to add to the debate concerning British overseas defence commitments during the immediate postwar years by casting it in an explicit opportunity cost framework. Indeed, defence responsibilities during the period constituted a classic example of this concept because they highlighted two sets of choices: those between civilian and military spending; and those inherent in the allocation of defence resources to different tasks.

The 1946 Defence White Paper drew attention to the 'guns versus butter' dilemma faced by Britain in the wake of six years of conflict when it stated that:

His Majesty's Government were confronted with a direct conflict of requirements. On the one hand, we could not abandon our responsibilities in many parts of the world. To do so would have been to throw away the fruits of victory and to betray 
those who had fought and died in the common cause. On the other hand, the necessity for our economic rehabilitation was imperative. ${ }^{1}$

British history in the 18 months following the end of the war with Japan is thus, in some respects, a tale of how the Labour Government, headed by Clement Attlee, sought to sustain these world-wide military commitments while attempting to rebalance the economy.

The conventional wisdom, exemplified by critics as diverse as Correlli Barnett and Edmund Dell, is that Britain's early post-war military efforts were predominantly attempts at great power posturing which merely prolonged austerity. ${ }^{2}$ Thus for Barnett it was clear that:

The crux of the problem of reconciling military costs with national impoverishment lay in this fantasy of the United Kingdom as a present and future 'centre of world influence and power, 3

By contrast, this article seeks to demonstrate that during 1945-47, at least, the Labour administration adopted a measured approach to overseas commitments and liquidated the most onerous, apart from Germany, in as orderly and dignified a fashion as circumstance allowed. More specifically, it is emphasised that: there was no realistic alternative to quitting India; Palestine was evacuated only after retention options had been exhausted; and Greece was supported until there was a strong likelihood that a transfer of the burden to the United States of America (USA) would be acceptable.

The liquidation of responsibilities took place against a background fear of Soviet expansionism and its consequences for the nation's security and long-term prosperity. There was thus an acute awareness that the Soviet Union would seek to exploit diminished British influence in Eastern Europe, the Middle East and the Indian subcontinent.

From a military perspective, the immediate post-war years constituted a unique period for the UK. The prime requirement was for an abundance of low cost/low technology infantrymen to police and garrison far-flung territories. This resource was provided mainly by existing forces no longer necessary for global conflict and a plethora of war-surplus equipment, available without resort to fresh investment. As a consequence the UK was able to field the largest peacetime forces in its history. Even so, the proportion of national income absorbed by defence declined from 18.8 per cent in 1946 to 7.6 per cent in 1948; while defence personnel contracted from 18.7 per cent of the male 18 to 44 age group to 8 per cent ${ }^{4}$. Hence, there would have been military manpower issues even if the economic situation had been less adverse. Only in the

\footnotetext{
${ }^{1}$ Ministry of Defence, Statement Relating to Defence 1946, 2-3.

${ }^{2}$ See for example, Barnett, The Lost Victory, 46-69 and Dell, The Chancellors), 68-70.

${ }^{3}$ Barnett, The Lost Victory, 51.

${ }^{4}$ Rosecrance, 'British Defense Strategy: 1945-1952' in Roscrance (ed) The Dispersion of Nuclear Weapons Strategy and Politics, 69.
} 
immediate aftermath of major and prolonged warfare was it acceptable for a democracy to maintain such a militarised society in peacetime.

Having taken the crucial steps in the abrogation of Great Power posture, policy makers were reluctant to acknowledge Britain's diminished status. This can be viewed as a failure of vision which delayed adaptation to changed circumstance. With the benefit of hindsight it is evident that the relative economic and strategic decline of the UK after 1945 was a permanent feature. However, this outcome was far from clear at the time. Thus a Foreign Office memorandum in early 1945 acknowledged the financial difficulties which would confront Britain after the war but ventured that:

There are sound reasons for hoping that they will be a temporary phenomenon, for this country possesses all the skills and resources required to recover a dominating place in the world economy. ${ }^{5}$

Moreover, even in retrospect, it is apparent that:

... the perception of British status as a world power in 1945 was not a folie de grandeur but a statement of the obvious. Britain was manifestly a world power possessing worldwide interests, military bases and substantial forces. ${ }^{6}$

There was therefore merit in attempting to maintain the nation's interests in an uncertain world during a transitional period, despite diminished resources and the adverse impact of government expenditure overseas.

The paper proceeds as follows. The next section considers Britain's challenging economic circumstances in 1945 and the extent to which military spending overseas weighed on the balance of payments. Following this, the most onerous external commitments, including the British occupied zone of Germany, are examined. Thereafter, the determining factors in the decisions to withdraw from the Indian subcontinent, Palestine and Greece are discussed. The final section reviews the consequences of retreat in terms of reduced military overstretch; balance-ofpayments alleviation; and the diminution in Britain's international status. It concludes that while the 1947 withdrawal decisions helped to bring Britain's Great Power status to a close, the reduction in military overstretch was achieved in as orderly a way as circumstances allowed.

\section{Britain's Post-war Economic Circumstances}

In 1945 balance-of-payments disequilibrium underscored the UK's economic difficulties. Before 1939, invisible earnings from foreign investments and services had normally covered visible trade and capital account deficits. The war destroyed this external balance mechanism. Many overseas assets had been sold or destroyed and

\footnotetext{
${ }^{5}$ [Kew, United Kingdom, The National Archives], F[oreign] O[ffice] papers 371/45694. 'Effect of External Financial Position on Foreign Policy’ 30 March 1945.

${ }^{6}$ Adamthwaite, 'Britain and the world, 1945-9: the view from the foreign office', 231.
} 
export markets neglected. ${ }^{7}$ At the same time, huge external Sterling debts (the Sterling Balances) were incurred in pursuit of victory. That stated, after November 1940 the war effort was not hampered by a dollar shortage because of the availability of the 'lend-lease' programme. This was 'undoubtedly an act of unexampled generosity" because it enabled the UK to draw on resources from the USA for the war's duration. Nevertheless, the scheme was subject to two highly restrictive conditions: it required the UK to fully exploit its resources prior to obtaining assistance; and support was not to be used to increase competitiveness in foreign markets.

Early in the war these restrictions were inconsequential. During 1943, however, Britain's post-war viability attracted attention because it would require enhanced international currency reserves and exports. By December 1944 the reserves had been partly replenished, mainly due to the stationing of US forces within the Sterling Area but the end of hostilities would lead to a rapid diminution in this currency flow. Moreover, in early 1945 the Allies assumed that there would be 18 months between Germany's surrender and Japan's defeat. The dropping of atomic bombs on Hiroshima and Nagasaki reduced the interval to three months. Resort to nuclear weapons saved numerous Allied lives but indirectly it placed the UK in a critical financial position because the abrupt end of hostilities resulted in a swift termination of lend-lease. The Government, therefore, decided to seek American financial assistance, so a mission was sent to Washington in September 1945.

The British negotiators emphasised the costs of the war to the UK. Exports were only 40 per cent of their 1938 level; merchant shipping amounted to less than threequarters of its pre-war tonnage; net income from overseas investment in 1945 was expected to be half that of 1938, while huge Sterling liabilities had accumulated. ${ }^{9}$ To achieve external balance, required export volumes some 75 per cent more than prewar: meanwhile, large balance-of-payments deficits would be incurred, partly because of temporary but substantial government expenditure overseas. ${ }^{10}$ The deficit in 1946 was likely to be about $£ 750$ million $(\mathrm{m})$ but was expected to decline until equilibrium was achieved, possibly in 1951. The USA was asked to fund the anticipated deficit by means of a grant of perhaps £5billion (bn) but the American response was a $\$ 3.75 \mathrm{bn}$ credit line which could be drawn upon prior to the end of $1951 .{ }^{11}$

While Britain sought to deal with the external payments problem, the main domestic task was the transition from a war economy. In mid-1945 there were still over 9m individuals either in the armed forces or supplying their needs. In principle, numbers could swiftly have been reduced to the 1939 level of $2 \mathrm{~m}$ since even this exceeded normal peacetime needs. In practice, extensive commitments - Britain policed more territory than at any time in its history - constrained the pace of diminution. During the inter-war period, defence strategy had been largely confined to ensuring UK security and keeping watch over an Empire. Despite problems, such as periodic protests across India and insurgencies in the Middle East, commitments did not, for

\footnotetext{
${ }^{7}$ For details see Hancock and Gowing, British War Economy, Chapter XIX.

${ }^{8}$ Sayers, Financial Policy 1939-45, 375.

${ }^{9}$ Treasury, Statistical Material Presented During the Washington Negotiations, Appendix 1.

${ }^{10}$ Ibid.

${ }^{11}$ Ibid. The Cabinet agonised over what repayments the UK could afford. In the event, the terms of the 50 year loan (which included a first repayment in 1950, an interest rate of 2 per cent and a waiver clause) proved relatively easy to meet. See Clarke, The Last Thousand Days of the British Empire,512.
} 
the most part, make undue demands on military resources. Post-war, the defence responsibilities of Empire were more challenging and there were fresh obligations in Western Europe, the Eastern Mediterranean and South-East Asia. Consequently, Britain was struggling to maintain order in India and Palestine while attempting to stabilise Greece. ${ }^{12}$ Moreover, occupation forces were required in Germany, Austria and Venezia Giulia. ${ }^{13}$ Troops were also needed to end the Japanese occupation of parts of South- East Asia ${ }^{14}$ and for a subsidiary role in the occupation of Japan. These global commitments were labour intensive, though the forces devoted to any one of them were far from constant. That stated, an indication of the scale of military requirements is given by a peak presence of roughly 150,000 troops in Italy and Austria and 80,000 in Greece.

For some 18 months after Japan's surrender, the UK attempted to maintain its military obligations while pursuing economic recovery. The authorities were unwilling to resolve the dilemma thus presented by abandoning major commitments. Instead, it was assumed that painful choices could be avoided because the dilemma would become less acute, or resolve itself, as economic recovery proceeded and 'abnormal' obligations declined. The Prime Minister, Clement Attlee, acknowledged that Britain's burdens were very heavy but argued that they resulted from the war and had to be fulfilled, if what had been won in the conflict was not to be lost. ${ }^{15}$ Acceptance of this view precluded rapid reversion to a pre-war military establishment. Only radical re-evaluation of the existing overseas stance could have permitted wholesale demobilisation. While passing consideration was given to such a policy, no action was taken. ${ }^{16}$

Even without a drastic curtailment of obligations, a major redistribution of personnel towards peacetime activities had proved feasible. Hence the October 1945 targets to reduce military personnel by $1.5 \mathrm{~m}$ and those producing supplies and equipment to $1.4 \mathrm{~m}$ by the end of the year had been achieved. ${ }^{17}$ The numbers in military-related activities had thereby been reduced by more than two-fifths. ${ }^{18}$ The following February the Cabinet's Defence Committee anticipated a further fall in service numbers to $1.2 \mathrm{~m}$ by the end of $1946 .{ }^{19}$ There thus appeared to be a reasonable prospect of achieving a trade-off between economic recovery and external commitments, provided that military resources were pruned to the minimum compatible with existing responsibilities. To this end, the 1946-47 defence estimates of $£ 1,803 \mathrm{~m}$ were reduced to $£ 1,667 \mathrm{~m}$, following pressure exerted by the Chancellor of the Exchequer, Hugh Dalton, ${ }^{20}$ who was convinced that economic circumstances precluded a continuance of existing policy. He pointed out that estimated foreign income for 1946 amounted to

\footnotetext{
${ }^{12}$ Ministry of Defence, Statement Relating to Defence 1946, 4-5.

${ }^{13}$ Ibid., 4.

${ }^{14}$ Ibid., 5 .

${ }^{15} 420$ House of Commons Debates (HC. Deb) 4 March 1946, Column (Col) 43.

${ }^{16}$ For some time after the war Attlee advocated Middle East withdrawal but the Chiefs of Staff and the Foreign Office were strongly opposed. See Dalton, High Tide and After, 101 and 105.

${ }^{17}$ Cmd. 6743, 3 .

${ }^{18}$ Ibid.

${ }^{19}$ [Kew, United Kingdom, The National Archives], CAB [inet papers] 129/7, 'Defence Policy in 1946.' Note by the Prime Minister and the Minister of Defence, 13 Feb.1946. In fact, more than 1.4m were in uniform on that date. See MoD, Statement Relating to Defence 1947, 6.

${ }^{20}$ CAB 129/7. 'Defence Policy in 1946.' Note by the Prime Minister and Minister of Defence, 13 Feb.1946.
} 
$£ 700 \mathrm{~m}$ while overseas spending would exceed $£ 1,500 \mathrm{~m}$, of which $£ 300 \mathrm{~m}$ would be for military purposes. ${ }^{21}$ The overseas deficit was therefore likely to be in excess of that contemplated by the Washington negotiators. ${ }^{22}$

In the light of such a pessimistic prediction, on 8 February Dalton cautioned the Cabinet in the following manner:

I must solemnly warn my colleagues that, unless we can reduce our overseas military expenditure drastically and rapidly, and avoid further overseas commitments, we have no alternative but to cut our rations and reduce employment through restrictions in the import of machinery and raw materials.

There is no way round this arithmetic and all our overseas policy must be conditioned by it. $^{23}$

The opportunity cost of military expenditure overseas in terms of domestic civilian spending was thus starkly stated.

To reinforce his plea for reduced commitments, Dalton asked John Maynard Keynes to prepare a paper outlining the state of Britain's finances and its author's views on the implications of his findings for policy. This paper was circulated to the Cabinet. ${ }^{24}$

Keynes argued that of a proposed import bill of $£ 1,075 \mathrm{~m}$ only $£ 40 \mathrm{~m}$ was inessential. In due course exports and invisible income would probably be able to finance anticipated imports but there was no prospect of financing current and anticipated military and political spending from foreign earnings. He advised the Cabinet that:

Ministers should not remain unwarned that they are going down the drain at a great pace, unless they can consider before it is too late whether a drastic and early change of policy may not be preferable. ${ }^{25}$

The solutions advocated in the paper included a reduction 'in forces outside Europe to 250,000 at the earliest possible date, ${ }^{26}$ at a time when plans provided for the maintenance of about 500,000 at the end of 1946. Keynes also advocated the withdrawal of British troops from Greece 'as soon as possible'. ${ }^{27}$

\footnotetext{
${ }^{21}$ CAB, 129/7, 'Balance of Payments for 1946.' Memorandum by the Chancellor of the Exchequer, 8 Feb. 1946.

${ }^{22}$ Ibid.

${ }^{23}$ Ibid.

${ }^{24}$ CAB. 129/7, 'Political and Military Expenditure Overseas', 8 Feb. 1946.

${ }^{25}$ Ibid.

${ }^{26}$ Ibid. Italics in original.

${ }^{27}$ Ibid.
} 
The combined onslaught of the Chancellor and Britain's most eminent economist had limited impact on the Cabinet. Meanwhile, economic developments appeared not to support Keynes' dire predictions.

The current account balance-of- payments outcome for 1946 exceeded expectations because the deficit was less than half that anticipated by the British negotiators of the American loan. Even so, Table 1 shows that the position had deteriorated markedly compared with 1938 because of changes in invisible flows. Despite their decline, private invisibles remained positive, leaving the rise in net government expenditure overseas as the prime reason for the failure to achieve external balance.

Table 1: UK Current Account of the Balance of Payments, 1938 and 1946

(£m at current prices)

19381946

\begin{tabular}{|l|c|c|}
\hline Visible Trade & -302 & -176 \\
\hline Invisible Trade & 232 & -172 \\
\hline of which: Government, net & -16 & -363 \\
\hline Other & 248 & 191 \\
\hline Current balance & $\mathbf{- 7 0}$ & $\mathbf{- 3 8 4}$ \\
\hline
\end{tabular}

Source: Extracted from Central Statistical Office (CSO) Annual Abstract of Statistics, No 93, (London: HMSO 1956) and Treasury, United Kingdom Balance of Payments 1946-50, Cmd. 8065, 1950.

Table 2 demonstrates that the state's increased external spending was largely military in origin.

Table 2: UK Overseas Government Transactions, 1946

(£m at current prices)

\begin{tabular}{|l|c|}
\hline Payments & 374 \\
\hline Military & 20 \\
\hline Administrative, diplomatic, etc & 123 \\
\hline Relief and rehabilitation & 10 \\
\hline Colonial grants & 527 \\
\hline Total & 164 \\
\hline Receipts & $\mathbf{3 6 3}$ \\
\hline War disposal, settlements, etc (net) & \\
\hline Total Government transactions &
\end{tabular}

Source: Extracted from Cmd. 8065.

\section{Onerous Overseas Commitments}

While the economic situation appeared to be improving, the assumption that commitments would shortly become markedly less burdensome was eroded by events to such an extent that sustaining them all ceased to be an option. In order to clarify how this position was arrived at, it is necessary to examine the part played by the four most onerous responsibilities: Germany, India, Palestine and Greece. 


\section{Germany}

In the aftermath of the Nazi defeat, the wartime allies - Britain, France, the USA and the Soviet Union - assumed responsibility for Germany's administration. Each had its own occupation zone. In March 1946, Attlee emphasised that by far the heaviest of all Britain's external commitments was: 'the occupation of the British Zone in Germany and the British sector in Berlin both by the provision of troops and for the maintenance of the strength of formations. 28

The intention had been to administer Germany as an entity. However, because the Soviet Zone was well-balanced detaching it was straightforward. Hence, by 1946 the Eastern sector was becoming a separate economic and political territory. The failure to administer Germany as one unit proved problematic for the UK because of the industrialised nature and diminished resources of the British Zone, which contained a population of some twenty million. The magnitude of the economic task was highlighted by the Director of Military Government in Germany who pointed out that the provision of food, fuel, and housing and, above all, communications and transport was much reduced compared with pre-war. ${ }^{29}$ By way of illustration, he explained that on VE-Day the railway system in the British Zone included 660 demolished bridges. ${ }^{30}$ Sustaining such a damaged economic entity was expensive. By mid-1946 the Zone had cost the Exchequer some $£ 38 \mathrm{~m}$ over and above the $£ 100 \mathrm{~m}$ attributable to military occupation. ${ }^{31}$ The commitment was onerous because much of it had to be met in dollars, thereby reducing UK imports from North America.

Dalton left his Cabinet colleagues in no doubt of the opportunity cost inherent in expending 'hard currency' in this manner: 'I have to ask the Minister of Food to cut down his dollar expenditure and so condemn our people to small and duller rations,. ${ }^{32}$

The Chancellor's recommendations for alleviating the German burden included some substitution of air force units for army personnel in the British Zone and the assumption by the USA of most of the non-military expenditure attributable to Germany. ${ }^{33}$ In December 1946 an agreement was signed for the fusion of the British and American zones and 'Bizonia' came into being at the start of 1947. As a consequence, by the year's end, the US had assumed responsibility for almost the entire non-military dollar deficit. Germany was, however, entwined with Britain's foreign relations to such a degree that the continued stationing of large land and air forces in the country was accepted, despite the financial sacrifice. Indeed, in the early 1950 's the British occupation forces metamorphosised into a military presence which

\footnotetext{
${ }^{28} 420$ H.C. Deb. British forces in Germany exceeded 200,000.

${ }^{29}$ See Templer, 'Military Government in Germany', 17.

${ }^{30}$ Ibid., 18.

${ }^{31}$ See CAB 129/10, 'The Cost of the British Zone in Germany'. Memorandum by the Chancellor of the Exchequer, 4 June 1946.

${ }^{32}$ Ibid.

${ }^{33}$ Ibid. The issue of how to reduce or eliminate the burden of the British Zone, without abandoning the objectives of the occupation was a matter of concern. See for example [Kew United Kingdom, The National Archives] T[reasury papers] 236/991 'Britain's Financial Policy in Germany', memorandum to the Chancellor from the Control Office for Germany and Austria, 16 Oct 1946.
} 
constituted a European defence commitment explicit with respect to both its size and duration. ${ }^{34}$

India

If stationing substantial forces in Germany was central to the UK's strategic interests, then any decision to sharply reduce forces overseas would need to focus elsewhere.

The withdrawal of forces stationed in India constituted one possibility.

The Indian Empire had long been a core component of Imperial defence. In addition to providing most of the forces needed for its own defence, the Raj played a major part in the protection of British possessions in the Middle East and South-East Asia. In essence, it provided the UK with a peace-time strategic reserve of about 250,000 men. The sub-continent was also invaluable as a location for military facilities. Substantial British forces, normally numbering some 70,000, were stationed in India as the ultimate safeguard of 'mother country' interests. Nevertheless, since the 1860s the military cost-benefit equation had been firmly in the UK's favour. By 1945, however, this comfortable state of affairs was in imminent danger of radical change.

Britain had indicated in 1917 that its goal was Indian responsible government but there was no implementation timetable. British procrastination was met by mass civil disobedience led by Gandhi, whose objective was independence. In 1929 the British announced that Dominion status would be the ultimate outcome of the 1917 statement but again without setting out a clear path. This omission was rectified in 1935 by the Government of India Act, which included the granting of provincial autonomy. However, while progress towards independence was discernable, ultimate authority continued in the hands of the Viceroy, the custodian of Imperial power. Hence, in 1939 the then Viceroy, Lord Linlithgow, 'had with tactless constitutional correctness simply announced that India was at war, without consulting its political leaders or the governments of the provinces'. ${ }^{35}$ Even so, Indian co-operation in the war effort was a valuable prize, so a mission headed by Sir Stafford Cripps was sent in March 1942 to barter a promise of post-war Dominion status for war-time support. ${ }^{36}$ The negotiations failed and Gandhi's response was to launch the 'Quit India' movement. The large war-time British military presence ensured that Imperial power prevailed during the ensuing power struggle. That stated, in Lord Wavell's judgement: 'Politically, the Cripps Mission in 1942 marked a stage in our (British) regression from power which it was never possible to retrace'. ${ }^{37}$

By 1945 Indian determination to terminate the Raj had hardened, while the UK's diminished economic power was underlined by India's huge Sterling Balances. In principle, Britain had already conceded the sub-continent's right to selfdetermination. Accordingly, in the light of previous assurances and prevailing circumstances, the Labour government committed itself to the early transfer of power.

\footnotetext{
${ }^{34}$ See Asteris, British Forces Germany.

${ }^{35}$ Toye, Churchill's Empire, 198.

${ }^{36}$ See Draft Declaration for Discussion with Indian Leaders (as published), Mansergh (ed), The Transfer of Power Vol.1, 565-571.

${ }^{37}$ See Wavell (Viceroy October 1943 to February 1947) letter to King George VI, 24 February 1947. Mansergh: Transfer of Power, 9, 802.
} 
Unfortunately, the obstacles to an orderly handover were formidable. Once independence loomed, the gulf between India's largely Hindu population and the Muslim majority in the North East and North West of the country widened. The two communities appeared united in little more than a distrust of the Colonial power. Consequently, British attempts to negotiate a constitution that would satisfy both communities within an independent united India ended in failure when, in June 1946, a cabinet mission, led by Sir Stafford Cripps, returned to the UK without achieving this goal. On the day of the Mission's departure, Wavell cautioned that: 'His Majesty's Government must be prepared for a crisis in India, at perhaps quite an early stage'. ${ }^{38}$ Civil war, with Britain attempting to hold the ring was now a distinct possibility.

Even before the breakdown of talks, the Cabinet had examined the options in the event of such an outcome. There were, as Cripps later emphasised, only two realistic courses of action. ${ }^{39}$ The first was for Britain to attempt to reassert her authority, while declaring an intention to remain for a further 15 years: alternatively, the Raj could be dismantled swiftly, with or without a constitutional settlement. ${ }^{40}$

A continued presence could have bought time to negotiate an agreement amongst the Indian communities, thereby minimising the possibility of an undignified withdrawal. However, the disadvantages of such a strategy were considerable. Maintenance of the Raj would have encountered bitter opposition from most sections of Indian and international opinion, while in Britain support for such action would have been far from unanimous. ${ }^{41}$ There were also immense practical obstacles to the continued maintenance of Imperial authority. Rapid Indianisation of the senior echelons of the Indian Civil Service and the Indian Army during the war had weakened the means by which Britain had controlled the sub-continent. Any attempt to replicate the traditional power structure would therefore require substantial troop reinforcements. ${ }^{42}$

The military implications of such a course of action were explained to the Cabinet in a memorandum from the Defence Committee. ${ }^{43}$ It concluded that if widespread disorders were to break out and the Indian armed forces became disaffected, a not unlikely course of events if Britain repudiated its independence commitment, then reinforcements of five divisions would be needed. ${ }^{44}$ The strategic implications of this requirement were far reaching. One division would have to be withdrawn from the Middle East, leaving insufficient forces to deal with a possible Arab uprising in Palestine. ${ }^{45}$ Both of the divisions in Greece would have to be redeployed, thereby ending direct military involvement in that country. ${ }^{46}$ A division would have to be withdrawn from Germany thus halving the occupation force and the only reserve

\footnotetext{
${ }^{38}$ Note for Cabinet on Present Position in India, 29 June 1946, Ibid, 7, 1085.

${ }^{39} 434$ H.C. Deb., 5 Mar.1947, Col.503.

${ }^{40}$ Ibid. Cols.503-504.

${ }^{41}$ More specifically, Attlee noted that public opinion, especially in the Labours Party, would not tolerate such a policy; he also doubted whether British troops would be prepared to act. See Mansergh, Transfer of Power, 9, 68.

${ }^{42}$ On 1 October 1946 there were 80,000 British troops in India: these were reduced to about 63,000 by 1 January 1947, Ibid. 519.

${ }^{43}$ CAB 129/10, 'India - Military Implications of Proposed Courses of Action'. The Defence Committee, 12 June 1946.

${ }^{44}$ Ibid. This assessment was underscored by the mutiny of the Royal Indian Navy in February 1946.

${ }^{45}$ Ibid.

${ }^{46}$ Ibid.
} 
division in Venezia Giulia would have to be removed. ${ }^{47}$ In addition, troops would be needed to replace Indian contingents in Burma and Malaya and possibly Hong Kong and Japan. Clearly, when measured in terms of Britain's military presence in Europe the Middle East and elsewhere, the opportunity cost of remaining in India would be very significant.

The alternative policy, withdrawal, offered two possible conclusions to Britain's presence: either an elegant demise of the Raj, or an undignified retreat. The Cabinet desperately wished to avoid the latter, not simply because it would represent a sad ending to an historic association but also because as the Foreign Secretary, Ernest Bevin explained: 'Any appearance of abandonment of our position in India without a solution would weaken our world position'. ${ }^{48}$

The remaining path was to continue the search for a constitutional settlement. The Cabinet concluded that, if this could be secured, independence would not appear to be the outcome of weakness; nor would it be interpreted as the first step in the Empire's dissolution. ${ }^{49}$ Since the Viceroy estimated that Britain's rule could not be effectively maintained beyond March 1948, it appeared opportune to make an early announcement of a withdrawal date. This could then be used to bring Hindus and Muslims together, thereby deriving advantage from an inevitable course of action. ${ }^{50}$ By the end of December 1946 it had been decided to adopt this approach. All that remained was to establish the date of the declaration concerning the withdrawal timetable.

\section{Palestine}

Despite the immense size disparity between India and Palestine, during 1946 the latter was, in some respects, equally problematic. The League of Nations had assigned the Palestine Mandate to the UK in 1922. In implementing it, Britain assumed an unworkable obligation: to create a Jewish national home and facilitate Jewish immigration into Palestine without prejudice to the Arab population. ${ }^{51}$ Arab hostility was apparent from the beginning. Initially this took the form of anti- Jewish violence but rising Jewish immigration culminated in an Arab revolt against British rule during 1936-39. To calm matters, the UK announced that within ten years it intended to create an independent Palestine, in which the two communities would share power. ${ }^{52}$ Meanwhile, immigration was to be limited to 75,000 during the five years from April 1939: additional numbers would require the consent of the Arab population. Neither community favoured this compromise but until the war's end the Palestine problem was relatively dormant.

\footnotetext{
${ }^{47}$ Ibid.

${ }^{48}$ CAB 129/10, 'The Situation in India and its Possible Effects Upon Foreign Relations'. Memorandum by the Foreign Secretary, 14 June 1946. 4. Bevin feared that if Britain left a vacuum in India then the Soviet Union would fill it.

${ }^{49}$ CAB 129/8, 108th Conclusions. Confidential Annex, 'India; Constitutional Position' 31Dec.1946.

${ }^{50}$ Ibid.

${ }^{51}$ Colonial and Foreign Office, Palestine: Termination of the Mandate.

${ }^{52}$ Colonial and Foreign Office, Palestine: Statement of Policy.
} 
In 1945 the immigration issue became more pressing because many Jewish survivors of Nazi persecution desired swift entry to Palestine. The British could not accept this demand because it would lead to another Arab revolt and threaten Britain's precarious predominance in the Middle East. Nevertheless, the political and economic muscle of the USA ensured that its interests had to be acknowledged. Consequently, an AngloAmerican Committee was appointed to examine the Palestine question. Meanwhile, the 1939 limit notwithstanding, ${ }^{53}$ monthly Jewish immigration of 1,500 was allowed. This ceiling was rejected by the Jewish community, thereby burdening British forces with the task of attempting to prevent illegal entry into Palestine. ${ }^{54}$ The Jewish response was a rise in terrorist activities.

The Committee reported in April 1946. It proposed the Mandate's continuation, the removal of restrictions on the purchase of Arab land and the immediate entry into Palestine of 100,000 Jewish settlers. The recommendations received a hostile reaction from Arab governments and the broader Muslim world, including such diverse organisations as the All-Indian Muslim League and the Ceylon Muslim League. ${ }^{55}$ The British were therefore unwilling to implement the Committee's report but sought to utilise its constitutional aspects. To this end, British and American officials recommended provincial autonomy for Palestine. However, the Jewish and Arab communities refused to accept this as a basis for discussion. Meanwhile, Britain sought to restore order by arresting many of Palestine's Jewish leaders. The Jewish response was to blow up the King David Hotel, which housed the Secretariat of the British Administration and Army in the territory. The explosion marked a hardening of British and Jewish attitudes. Hence, the security situation continued to deteriorate, despite a substantial military presence. Alarmingly, if the UK were to attempt an imposed solution, much greater forces would be required. Thus, despite the sparse prospects of success, at the close of 1946 the British were still attempting to negotiate a compromise arrangement which would leave them in overall authority. This desire to maintain the Mandate was strongly motivated by strategic considerations in the light of Britain's uncertain military presence in Egypt. ${ }^{56}$

\section{Greece}

During the German occupation of Greece between 1941 and 1944, the Communists became the strongest resistance faction. Britain's wartime Prime Minister, Winston Churchill, appreciated that a Nazi withdrawal would prompt a Communist attempt to seize power. Consequently, British forces were landed in Greece in October 1944, immediately after the Germans commenced their retreat. At the same time, Churchill and the Soviet leader, Joseph Stalin, arranged a temporary Balkan settlement on the basis of an unofficial 'percentage agreement'. This gave Russia 90 per cent predominance in Rumania, while Britain, in accord with the USA, had 90 per cent

\footnotetext{
53433 HC. Deb., 19 Feb. 1947, Col. 990.

${ }^{54}$ There was extreme reluctance to approve interception on the high seas of vessels carrying illegal immigrants, even though the arrival of ships caused disturbances in Palestine. See [Kew, United Kingdom, The National Archives] C[olonial] O[ffice papers] 537/2389 'Illegal immigration: Interception of vessels destined for Palestine', 1947.

${ }^{55}$ For details, see CO 733/463/17, 'Middle East, Palestine: Anglo-America Committee Report, Arab Reactions' April/May1946.

${ }^{56}$ See Ovendale, 'The Palestine Policy of the British Labour Government 1947: The Decision to Withdraw', 76, 78 and 84.
} 
predominance in Greece. ${ }^{57}$ The understanding ensured that the British entered Athens peacefully. Even so, the Communists controlled much of Greece, hence Churchill recognised that they would try to seize power. He was determined to resist such a move by using British troops to support the Royal Hellenic Government. ${ }^{58}$

In December civil war commenced with a Communist attempt to takeover Athens and the areas of Greece not under their influence. The arrival of reinforcements enabled the British to prevail and in February 1945, a peace treaty was signed. This provided for a plebiscite on the position of the monarchy.

Churchill had now achieved his prime objective: to provide a foundation for a Greek government capable of raising 'a national force to preserve itself in Attica. ${ }^{59}$

Nonetheless, it was clear that military and economic aid would continue to be needed but Britain was providing only the minimum necessary to prevent regime change. Hence, her forces were not available for operations outside of the Athens vicinity. Over the rest of the country, the situation was problematic but the Greek Army, maintained with British help, prevented it becoming hopeless. Throughout the fighting in Athens the Russians restrained their comments but the American press was critical of British actions. Policy towards Greece also had many Labour Party critics, though its leaders supported Churchill's approach. Consequently, the July 1945 formation of a Labour government made little difference to support for Greece. Bevin underlined the continuity of policy when he stated that 'we must maintain our position in Greece as part of our Middle East policy'. ${ }^{60}$ Nevertheless, Greece continued to be a sensitive issue within the Labour Party even after elections were held in that country in April 1946.

Despite an elected government, Greece remained in a perilous position. The new administration lacked the military resources necessary for control of the entire country but Britain was unwilling to provide more support. Indeed, by late May, consideration was being given to the financial assistance necessary to permit the withdrawal of army units at the end of the summer. ${ }^{61}$ Dalton continued to argue for an end to what he later termed 'the endless dribble of British taxpayers' money to the Greeks. ${ }^{62}$ By contrast, Bevin remained in favour of compensating for military withdrawal by providing the Greek Army with stored equipment which would not involve the UK in additional costs. ${ }^{63}$

Earlier aspirations notwithstanding, British forces were still stationed in Greece during late 1946, by which time the security position was deteriorating rapidly. Guerrilla activity in northern Greece, supported by bordering countries, threatened the government and economic reconstruction. The British, however, avoided additional involvement and the Greeks were made aware of reluctance to continue support. Greece was therefore encouraged to seek assistance from the USA, which was more

\footnotetext{
${ }^{57}$ Churchill, The Second World War, Vol. 6, 198.

${ }^{58}$ Ibid., 50.

${ }^{59}$ Ibid., 268.

${ }^{60}$ CAB 129/1, 'Greece'. Memorandum by the Secretary of State for Foreign Affairs, 11 Aug.1945.

${ }^{61}$ CAB 129/10, 'Greece'. Memorandum by the Secretary of State for Foreign Affairs, 30 May 1946.

${ }^{62}$ Dalton, High Tide and After, 206.

${ }^{63}$ CAB 195/4 'Greece: Cost of Armed Forces', 3 June 1946.
} 
sympathetic than hitherto because the Truman Administration was reassessing its foreign policy.

In early 1946, the Americans regarded British efforts to contain the Soviet Union as an attempt to sustain national interests. Overall, US policy towards Russia had been more accommodating than that of Britain. This stance precluded close identification with Britain's objectives in Greece. Evidence of a changed approach was provided in March 1946, when the UK and the US resisted a Soviet attempt to include Iran in its sphere of influence. In August, there was a further indication of America's changing attitude towards the Eastern Mediterranean and the Middle East. The Soviet Union sought to obtain a revision of the Montreux Convention, so as to permit joint TurkishSoviet defence of the Dardanelles. When, in response, the US sent naval units to the area, the Russians ceased to press the issue. Hence, by late 1946, the USA was increasingly sympathetic towards Britain's containment policy.

\section{The Withdrawal Decisions}

As already noted, the UK's 1946 current account deficit was less than half that anticipated in late 1945. Indeed, in real terms, the trade deficit was less than one-third of that immediately prior to the war. The deterioration in the current account was therefore due to changed invisible flows. While much reduced, private invisible earnings remained positive. This left the huge rise in net government expenditure overseas, detailed in Table 2, as the prime cause of the failure to achieve external balance in 1946 . While, at $£ 374 \mathrm{~m}$, military outlays constituted the largest outflow, it is evident from the table that $£ 123 \mathrm{~m}$ was also expended on overseas relief and rehabilitation, of which Germany accounted for $£ 40 \mathrm{~m}$.

The authorities were encouraged by the overall payments position but concerned about specific features. First, the lower trade deficit compared with 1938 was primarily due to restrictions on overseas purchases of food and raw materials. ${ }^{64}$ Second, by the end of 1946 drawings on the American loan totalled $\$ 600 \mathrm{~m}$, a rate of utilisation, which, if continued, would exhaust the credit by September 1949. ${ }^{65}$ Third, government outlays overseas far exceeded the rate allowed for in the loan agreement. Thus, analysis of the 1946 balance of payments indicated a painful path ahead, namely; increased exports, import restriction and reduced government overseas expenditure. Fortuitously, at this juncture, economic factors neatly coincided with political and military developments.

In early 1947 , the post-war recovery was temporarily halted by a shortage of coal, a fuel upon which the British economy depended. To conserve stocks, coal exports had recently been suspended. However, fuel availability remained constrained, so in an effort to ensure supply continuity, coal allocations to industry were halved in midJanuary. Unfortunately, between January and March, a succession of blizzards disrupted the mining and distribution of coal. Limited stock holdings ensured that the effect on economic activity was almost immediate. On 7 February, the authorities announced harsh power-conserving measures designed to maintain essential

\footnotetext{
${ }^{64}$ Treasury, Economic Survey for 1947, 11-12.

${ }^{65}$ Dalton, High Tide and After, 221.
} 
services. ${ }^{66}$ The crisis resulted in a temporary rise in unemployment to over two million.

In the midst of the grim domestic economic situation, two dramatic policy statements relating to overseas commitments were made to the House of Commons. Following a Cabinet decision of 14 February, ${ }^{67}$ the Foreign Secretary divulged on 18 February that the Government had abandoned the attempt to achieve a negotiated settlement in Palestine under its own auspices and that since, under the terms of the Mandate, it felt unable to impose a solution unilaterally, the problem was to be referred to the United Nations (UN). ${ }^{68}$ On the same day, the Cabinet set the date for the ending of the Raj ${ }^{69}$ and so, on 20 February, the Prime Minister announced that the British Government intended to withdraw its military forces and government officials from India by June $1948 .^{70}$ A day later, the Treasury gave the United States notice that Britain would terminate its support to Greece on 31 March.

The British had indicated in the autumn of 1945 that US financial aid to Greece would be welcome. ${ }^{71}$ However, although the Americans had helped through indirect channels, they had left the prime support responsibility to the UK. Nevertheless, in late 1946, the Greek Government approached the Americans to ascertain what new assistance the latter might provide. President Truman delayed a decision by dispatching an Economic Mission to Greece in January 1947. Meanwhile, Dalton intensified his efforts to end British expenditure in Greece. Until mid- February Bevin continued to resist but then agreed that the USA should be informed that Britain had decided to terminate its aid. ${ }^{72}$

During early 1947, the United States monitored the deteriorating British economy. Meanwhile, reports from Greece became increasingly alarming. On 3 February, the American ambassador reported rumours that the British were about to make further troop withdrawals. ${ }^{73}$ Nine days later he recommended immediate aid for Greece because of Britain's inability to cope with the situation. ${ }^{74}$ On 18 February, Truman was warned that the signs pointed to a renewed Communist offensive and two days later the American Embassy in London communicated Treasury opposition to further aid for Greece because of the UK's own financial position. ${ }^{75}$ The US therefore anticipated being faced with a Greek crisis but crucial decisions were required sooner than expected. ${ }^{76}$

\footnotetext{
${ }^{66} 432$ H.C.Deb., 7 Feb. 1947, Cols.21 82-3.

${ }^{67}$ CAB 128/9, 22nd Conclusions, 'Palestine Future Policy'14 Feb.1947.

${ }^{68} 433$ H.C. Deb., 18 Feb. 1947, Col. 988.

${ }^{69}$ See CAB 128/11, 23rd Conclusions, Minute 1 Confidential Annex, 'India: Constitutional position'18 Feb. 1947.

${ }^{70}$ Ibid., 20 Feb.1947, Cols. 1395-1398.

${ }^{71}$ Truman, Memoirs Vol. 2, 104. See also, Ferrell, American Secretaries of State and their Diplomacy, Vol.15, 78.

${ }^{72}$ Dalton, High Tide and After, 206-207.

${ }^{73}$ Truman, Years of Trial and Hope, 104. On that day Britain informed Greece that British forces in the country were to be reduced from 16,000 to 8,000 men.

${ }^{74}$ Ibid., 105.

${ }^{75}$ Ibid.

${ }^{76}$ Ibid
} 
On 21 February, two British notes relating to Greece and Turkey were received by the State Department. ${ }^{77}$ The first recalled that both countries were agreed on the need to prevent Greece and Turkey becoming part of the Soviet sphere and that the US had agreed to give Greece economic aid. Since the economic situation in Greece was desperate, Britain considered it essential for the United States to make an immediate decision on possible assistance. In 1947 Greece would require between $£ 60 \mathrm{~m}$ and $£ 70 \mathrm{~m}$ in foreign exchange from outside sources but the UK was unable to assist beyond 31 March. The note expressed the hope that the US would accept the responsibilities that Britain was relinquishing. ${ }^{78}$

The second note emphasised that Turkey needed to improve her military capability, while pursuing a programme of economic development but could not do both from her own resources. The UK was, however, unable to provide further assistance, so the obligation would have to fall on the US or the International Bank.

In the light of the British notes, the Truman Administration prepared to intervene in the Eastern Mediterranean. After ensuring the approval of Congressional leaders, the President addressed a joint session of Congress on 12 March. He outlined the situation in Greece and Turkey and placed the crisis in the context of an ideological confrontation between the United States and the Soviet Union. The President then came to the heart of his address, which became known as The Truman Doctrine:

I believe that it must be the policy of the United States to support free people who are resisting attempted subjugation by armed minorities or by outside pressures.

I believe that we must assist free peoples to work out their destinies in their own way. $^{79}$

Congress was asked to provide authority for $\$ 400 \mathrm{~m}$, to be shared between Greece and Turkey and for permission to send civilians and military personnel to supervise reconstruction and training. Both Houses of Congress approved the proposals by a comfortable majority.

The rapid and dramatic response to the British notes in part reflected a conviction that Britain was facing catastrophe. Joseph M. Jones, a member of the State Department, provided an account of how Americans viewed developments:

Great Britain was finished as a world power! Suddenly the steady, pounding daily news reports of the previous year and a half formed a pattern: the strongest bastions of the imperial system had collapsed - India, Burma, Egypt, Palestine; elsewhere Britain's authority was being reduced to a shadow because of troop withdrawals and

\footnotetext{
${ }^{77}$ The summary of the communications which follows is based upon the account by. Jones, The Fifteen Weeks, 5-7.

${ }^{78}$ Subsequently, the Americans learned that Britain intended withdrawing her forces from Greece as soon as could be arranged. Truman, Years of Trial and Hope, 81.

${ }^{79}$ Congressional Record, Eighteenth Congress, first session, 1981.Reprinted in Barton, Bernstein and Matusow (Eds). The Truman Administration, 255.
} 
reductions in financial and political aid; and now the citadel of the Empire, Great Britain, heavily in debt and unable to sustain itself even with generous aid, faced collapse. $^{80}$

On 22 March, The Economist newspaper reflected upon the American interpretation of events and presented a less dramatic explanation of the situation:

The snowfall by exaggerating the shape of things in Britain revealed to a people accustomed to complain of the difficulties of life with father, what life would be like with father no longer there. The rather-too-promptly published obituaries seemed, many of them to take insufficient account of the likelihood of a spring thaw...But the assessment of the British position however inaccurate, underlined implications of the overseas position which might have been taken lightly or ignored. Pax Britannica is over. Who then shall be the keeper of the peace? ${ }^{81}$

President Truman provided the answer.

The timing of the British announcements relating to reduced overseas commitments appeared to indicate that they were closely related to the domestic economic crisis of early1947 but the link was tenuous. Whilst the need to lighten external responsibilities had been evident for many months, the selection of which burdens should be relinquished was primarily determined by political and military considerations. ${ }^{82}$

After the war, the British recognised that Western Europe's economic weakness, combined with the Soviet presence in Central Europe, necessitated United States involvement in the European power balance. ${ }^{83}$ By contrast, the desire of the Americans was to minimise their participation in global affairs. ${ }^{84}$ This attitude compelled the British to attempt a holding operation against Soviet expansionary pressure in the Eastern Mediterranean and the Middle East, while awaiting a change in American opinion which would permit more equitable burden sharing.

In the Indian Ocean, the problem was nationalism, rather than Soviet pressure. From a strategic perspective, the region was less significant to the UK than Europe or the Middle East. Britain was therefore reluctantly willing to come to terms with changing circumstances, even though the Raj was the most important component of the Empire. The decision to grant India independence was thus the product of earlier promises, expediency, a decline in prestige and a fear of being sucked into a magnified version

\footnotetext{
${ }^{80}$ Jones, The Fifteen Weeks, 81.

${ }^{81}$ The Economist, 22 Mar, 1947, 415.

${ }^{82}$ Though shedding major obligations in the midst of a domestic fuel crisis probably stemmed criticism that the UK was acting irresponsibly.

${ }^{83}$ This recognition notwithstanding, notions of a third-world force, based on UK leadership of a EuroAfrican grouping, enjoyed a degree of Foreign Office and Labour Party support. See Kent 'Bevin's Imperialism and the Idea of Euro-Africa, 1945-49' in Dockrill and Young (eds) British Foreign Policy, 1945-56. This 'third force' concept underlines the fact that the end of the Raj did not signal a readiness to accept rapid decolonisation in Africa.

${ }^{84}$ The Soviet Union cultivated this sentiment by making Britain the primary target of hostility. See Williams, Ernest Bevin,255.
} 
of Palestine.$^{85}$ In the final analysis, a war-weary country recognised that the aspirations of the sub-continent were such that little was to be gained by attempting to rule by force over an extended period, even assuming that the necessary troops could be made available.

Within six months the liquidation of the Raj was followed by the independence of Burma and Ceylon. The former had been separated from the Indian Empire in 1937. Five years later it was occupied by the Japanese, who declared it independent. British rule was restored in 1945 but Burma had been assured in1931 that its constitutional progress would keep in step with that of India. Moreover, by the war's end, Burma had a strong nationalist movement sensitive to Britain's past promises and determined to dispense with alien rule.

The UK's grip on power had been critically weakened by the Japanese occupation and the lack of dependable military resources placed the authorities at a disadvantage. There were doubts as to the loyalty of the Burmese battalions and the availability of Indian troops; leaving 'three weak British battalions' as the only reliable forces. ${ }^{86}$ Consequently, if the response to nationalist demands proved inadequate and rebellion resulted, substantial British reinforcements would be required. These could only be provided by slowing demobilisation, which the UK Government was loath to contemplate. This inability or unwillingness to deploy sufficient troops so as to restore effective control led to Burma gaining independence outside the Commonwealth in January 1948.

Once self-determination had been ceded to Burma, it was difficult to deny Ceylon a similar outcome when she had proved more loyal during the war. The authorities were also mindful of the advice of Lord Soulbury, the Chairman of the Ceylon Commission on Constitutional Reform, to the effect: 'that in the long run giving too much and too soon will prove to be wiser than giving too little and too late'. ${ }^{87}$ A month after Burma, Ceylon also became independent. However, in contrast to the outcome in India, Pakistan and Burma, Britain retained a number of military establishments, including the Trincomalee naval base.

The submission of the Palestine question to the UN was the product of political and military considerations in both origin and timing. It represented a response to the rejection by both Jewish and Arab representatives of compromise proposals for a settlement. ${ }^{88}$ Palestine was undoubtedly a military burden, which had cost $£ 82 \mathrm{~m}$ in the previous two years ${ }^{89}$ and was currently absorbing 84,000 troops. ${ }^{90}$ That stated, financial and manpower issues played a secondary role in referring the problem to the UN since, in his February announcement, Bevin indicated that the Government was

\footnotetext{
${ }^{85}$ In his final letter to George VI as Viceroy, Wavell expressed the view that: 'Our power in India has always depended on prestige rather than on numbers; and it is the decline in our prestige rather than the lack of numbers that has reduced our control in India to its present state of something approaching impotence.' See Mansergh, Transfer of Power, 9, 805.

${ }^{86}$ See General Officer Commanding Burma Command to War Office. Tinker (ed) Burma: The Struggle for Independence 1944-48 Vol. 1I, 189-190.

${ }^{87}$ Letter from Lord Soulbury to Mr Hall (Secretary of State for the Colonies) in Hyam (ed) British Documents on the End of Empire, Series A, Vol.23, 4-5.

${ }^{88}$ Palestine: Termination of the Mandate, .9 .

${ }^{89} 434$ H.C.Deb., 6 Mar. 1947, Col.651.

${ }^{90} 433$ H.C. Deb., 18 Feb. 1947, Col.933.
} 
willing to wait until the next regular session of the General Assembly the following September. ${ }^{91}$ Meanwhile, there was no question of substantial force reductions in Palestine. The subsequent decision to request an early special session of the Assembly was motivated by the worsening security situation in Palestine, external disdain for Britain's role and the pressure of domestic public opinion.

The Assembly addressed the issue by appointing an investigatory committee. In August this recommended partition and an early end of the Mandate. During a transitional period, Britain was to be responsible for implementing the Committee's proposals. Partition was, however, anathema to the Arab states, so responsibility for implementing it would have been highly disadvantageous to the UK. It was therefore made clear that without a solution that had the support of sides, Britain's forces and administration would be withdrawn at an early date. Nevertheless, the Assembly voted for partition. In the light of earlier statements, the UK had little option but to withdraw. On 11 December it was announced that the Mandate would terminate on 15 May 1948 and all British forces would leave by 15 August. $^{92}$ Financial factors appear to have had limited influence on the course of events leading to the withdrawal.

Only in the case of Greece is there substantial evidence indicating that economic constraints were a crucial element in the abrupt decision to abdicate responsibility for that country. However, even in this instance, financial factors were, arguably, not of themselves decisive. In common with Palestine, Greece had been a heavy burden in the two years prior to February $1947 . .^{93}$ That stated, despite the onslaught of Dalton and Keynes, Bevin had retained the obligation for the financial year 1946-47. Moreover, in the face of the Chancellor's opposition, he continued to urge support for Greece at the Cabinet meeting on 30 January. The meeting did not resolve the issue However, the Foreign Secretary was invited to convene a combined Foreign Office, Treasury and Ministry of Defence committee to consider the financial implications of assisting Greece and what proposals should be put to the US. ${ }^{94}$ This convened on 1 February. Two weeks later Bevin advised the Chancellor that; 'I think it would be useful if you and I could have an early discussion about this Greek matter and on the whole matter of financing our foreign policy ... ${ }^{95}$ On 18 February they met and agreed that their officials would settle the final wording of the Treasury communication to the Americans. That Bevin consented to relinquish responsibility for Greece at short notice largely as a consequence of the economic situation seems doubtful. He was second only to Attlee in terms of his Cabinet influence and had learnt the skills of negotiation and compromise during his years as a trade union leader. Thus, he could have offered expenditure reductions elsewhere in order to retain a minimal flow of aid to Greece, which the US could have been requested to supplement. That he did not do so indicates that acquiescence in abandonment constituted a contrivance to entice the US into accepting responsibility for Eastern Mediterranean security. ${ }^{96}$

\footnotetext{
${ }^{91}$ Ibid. Moreover, as late as mid -January, the Chief of the Imperial Staff advised the Cabinet that he would propose military reinforcements for Palestine 'at the expense of our forces in Germany' should the situation so require. See CAB 128/11, 'Palestine: Implications of Future Policy', 15 January 1947. ${ }^{92}$ Palestine: Termination of the Mandate, 9. The British left without any formal transfer of power.

${ }^{93}$ Total expenditure amounted to about $£ 87 \mathrm{~m}$. 434 H.C Deb., 6 Mar. 1947, Col.651.

${ }^{94}$ CAB128/9, 14th Conclusions 'Greece and Turkey' 30 January 1947.

${ }^{95}$ FO 37/167032, Letter from Bevin to Dalton, 15 February 1947.

${ }^{96}$ This was the interpretation placed upon the decision by, Francis Williams. See Williams, Ernest Bevin, 263-264. See also Bullock, Ernest Bevin, 368-370.
} 
British intervention in Greece sought to deny the country to the Communists but the need to obtain American participation in the task was acknowledged. By 1947 the US appreciated that Russian domination of the Eastern Mediterranean would indirectly, threaten its own security. Bevin was acutely aware of the changing American view and understood its implications in terms of relieving the UK of an arduous task, while increasing American involvement in Europe. ${ }^{97}$ Inviting the US to accept responsibility for Greece was, of course, a gamble which might not have been taken but for Treasury pressure at a difficult time. In retrospect, Bevin showed excellent judgement in his choice of issue and timing, thereby turning Britain's temporary rigor mortis to advantage.

Even Dalton's selection of Greece for financial savings cannot be solely attributed to economic pressures since it is difficult to escape the conclusion that he was partly motivated by the conviction that, because of the nature of its government, the country was less worthy of British outlays than a number of other commitments. Hence, when in order to placate the Americans, Bevin succeeded in maintaining some financial and military assistance to Greece beyond $31 \mathrm{March}$, Dalton expressed his irritation to the Prime Minister, adding: 'I regard the Greeks as a very poor investment for the British taxpayer.' 98

\section{Conclusion}

The last troops British troops left India in March 1948. ${ }^{99}$ The evacuation of Palestine was completed the following June. ${ }^{100}$ Remaining forces in Greece were also further reduced though, to please the US, a contingent remained until the end of the Civil War in early 1950.

Table 3, reveals that these departures, together with the drawdown of other foreign military commitments ${ }^{101}$ resulted in a rapid curtailment of net overseas government expenditure to $£ 230 \mathrm{~m}$ in 1947 and $£ 113 \mathrm{~m}$ in 1948 , less than a quarter of the figure for 1946. The drastic reduction in 'overstretch' advocated by Dalton and Keynes had thus been achieved.

\footnotetext{
${ }^{97}$ In a memorandum to the Cabinet he argued that it was essential to know what aid the US was prepared to offer over three years. See CAB 129/16, 'Policy Towards Greece and Turkey', 25 January 1945.

${ }^{98}$ FO 37/67040, Memorandum from Dalton to Attlee, 18 April 1947. On 1 May there were still 8,102 British troops in Greece. See FO 371/67042, 'Aid to Greece by United Kingdom and United States, May 1947

${ }^{99}$ Prior to 15 August it was announced that, after independence, British forces would not intervene in the event of internal disorder. However, secret orders specified when British troops might be deployed to protect British lives. See Directive from Sir A. Smith 29 July 1947, Mansergh, Transfer of Power 12, 267.

${ }^{100}$ Though a report was prepared, outlining possible opposition from either Arabs or Jews should it prove necessary for the territory to be reoccupied 'by British forces alone or by combined AngloAmerican forces'. See CO 537/4126, Report by the Joint Intelligence Committee, 'Middle East Defence: Possible Re-occupation of Palestine in the event of War with Russia'. 11 September 1948.

${ }^{101}$ For example, British troops had been withdrawn from Indonesia, Lebanon, Syria and Vietnam by the end of 1946 and from Italy by December 1947.
} 
Table 3: UK Overseas Government transactions, 1947 and 1948

( $£ \mathrm{~m}$ at current prices)

\begin{tabular}{|l|c|c|}
\hline & $\mathbf{1 9 4 7}$ & $\mathbf{1 9 4 8}$ \\
\hline Payments & & 113 \\
\hline Military & 209 & 29 \\
\hline Admin. diplomatic etc & 25 & 31 \\
\hline Relief and rehabilitation & 118 & 10 \\
\hline Colonial grants & 7 & 183 \\
\hline Total & 359 & \\
\hline Receipts & & -96 \\
\hline War disposals etc) & -129 & $\mathbf{8 7}$ \\
\hline Total Govt. transactions & $\mathbf{2 3 0}$ & \\
\hline
\end{tabular}

Source: Extracted from Cmd. 8065.

Britain's economic weakness in 1945 dictated the curtailment of foreign obligations if her people were not to be denied a peace dividend. Nevertheless, this paper has sought to demonstrate that against an unfavourable financial background, the selection and timing of major reductions in commitments was primarily determined by political and military considerations, rather than financial necessity. Important decisions involving overseas posture were made in late 1946 and early 1947. Priorities in the allocation of defence resources were decided with a clear perception of the alternatives foregone. Hence choice, rather than economic compulsion, was the determining factor. Moreover, the Labour Government remained determined to maintain its extensive residual global responsibilities, albeit in alliance with the United States.

In terms of domestic resource allocation, the immediate cost of not bowing to economic pressures in 1945/46 was considerable. However, this self-sacrifice was beneficial in the longer term because the nation could 'never hope to restore its economy and its export trade, raise its own standard of living and keep its industries fully occupied in a world deprived of ordered and peaceful conditions for development'. ${ }^{102}$ The UK lacked the resources to finance the reconstruction of devastated economies. This task was undertaken by the US, once she accepted the implications of her post-war status. Meanwhile, Britain attempted, with varying degrees of success, to maintain stability in many parts of the globe. With hindsight, it is evident that the momentous announcements of February 1947 heralded Britain's demise as a great power. Even so, the record indicates that, despite the harsh economic realities, the Attlee government, underpinned by the American loan,

\footnotetext{
102 This statement formed part of the reply by the Minister of Defence in March 1947 to criticisms of the level of defence spending. See 433, H.C.Deb., 20 Mar. 1947, Col.435.
} 
reduced Britain's military overstretch in the immediate aftermath of war as rapidly and responsibly as circumstances permitted.

\section{Bibliography}

Adamthwaite, Anthony, 'Britain and the world, 1945-9: the view from the foreign office' International Affairs. 61 (2) 1985, 223-235.

Asteris, Michael, British Forces Germany; Size Versus Presence, Whitehall Paper (London: Royal United Services Institute For Defence Studies, 1987).

Barnett, Correlli, The Lost Victory: British Dreams, British Realities 1945-1950 (London: Pan Macmillan 1996).

Bernstein, Barton. J. and Matusow, Allan, J., (Eds). The Truman Administration, A Documentary History (New York: Harper and Row 1966).

Bullock, Alan, Ernest Bevin, Foreign Secretary: 1945-51 (London: Norton 1983).

Central Statistical Office, Annual Abstract of Statistics, No 93 (London: HMSO 1956).

Churchill, Winston. S., The Second World War, Vol. 6, Triumph and Tragedy (London: Cassell 1954).

Clarke, Peter The Last Thousand Days of the British Empire (London: Penguin Books 2008).

Colonial and Foreign Office, Palestine: Statement of Policy, Cmd. 6019, (London: HMSO 1939).

Colonial and Foreign Office, Palestine: Termination of the Mandate, 15 May 1948, (London: HMSO 1948).

Dalton, Hugh, High Tide and After, Memoirs 1945-1960 (London: Muller 1962).

Dell, Edmund, The Chancellors (London: Harper Collins 1996).

Ferrell, Robert. H., American Secretaries of State and their Diplomacy, Vol. 15. George C. Marshall (New York: Cooper Square 1966).

Hancock, William. C., and. Gowing, Margaret. M., British War Economy (London: HMSO 1949).

Hyam, Ronald (ed) British Documents on the End of Empire, Series A, Vol.2 (London: HMSO 1992).

Jones, Joseph. M., The Fifteen Weeks (New York: The Viking Press 1955).

Kent, John, 'Bevin's Imperialism and the Idea of Euro-Africa, 1945-49 in Dockrill, Michael and Young, John, British Foreign Policy, 1945-56 (London: Macmillan 1989).

Ministry of Defence, Statement Relating to Defence 1946, Cmd.6743. (London: HMSO 1946).

Ministry of Defence, Statement Relating to Defence 1947, Cmd. 7042. (London: HMSO 1947).

Mansergh, Nicholas (ed), The Transfer of Power, 1942-7, Vols.1, 7, 9 and 12 (London: HMSO 1970-83).

Ovendale, Ritchie, 'The Palestine Policy of the British Labour Government 1947: The Decision to Withdraw'. International Affairs 56 (1) 1980, 73 - 93.

Rosecrance, Richard. N., 'British Defense Strategy: 1945-1952' in Rosecrance, Richard, N., (ed) The Dispersion of Nuclear Weapons: Strategy and Politics (New York: Columbia U P 1964).

Sayers, Richard. S., Financial Policy 1939-45 (London: HMSO and Longmans Green 1956).

Templer, Gerald, Military Government in Germany, Journal of the Royal United Service Institution, XCI, 561, 1946, 17 - 37.

Tinker, Hugh (ed) Burma: The Struggle for Independence, Vol II, From General Strike to Independence, 31August 1946 to 4 January 1948 (London: HMSO 1984).

Toye, Richard, Churchill's Empire, London: Macmillan 2010).

Treasury, Statistical Material Presented During the Washington Negotiations, Cmd. 6706 (London: HMSO 1946).

Treasury, Economic Survey for 1947, Cmd. 7046 (London: HMSO 1947).

Truman, Harry S. Memoirs, Vol. 2, Years of Trial and Hope, 1946-1953 (Garden City, New York: Doubleday 1956).

Williams, Francis, Ernest Bevin: Portrait of a Great Englishman (London: Hutchinson 1952). 